\title{
BMJ Open Perceptions of medical students towards online teaching during the COVID-19 pandemic: a national cross-sectional survey of 2721 UK medical students
}

\author{
Samiullah Dost (D) , ${ }^{1}$ Aleena Hossain (D) , ${ }^{2}$ Mai Shehab (D) , ${ }^{3}$ Aida Abdelwahed (D) , ${ }^{2}$ \\ Lana Al-Nusair (1)
}

To cite: Dost S, Hossain A, Shehab M, et al. Perceptions of medical students towards online teaching during the COVID-19 pandemic: a national cross-sectional survey of 2721 UK medical students. BMJ Open 2020;10:e042378. doi:10.1136/ bmjopen-2020-042378

- Prepublication history and supplemental material for this paper is available online. To view these files, please visit the journal online (http://dx.doi. org/10.1136/bmjopen-2020042378).

$\mathrm{SD}$ and $\mathrm{AH}$ contributed equally.

$\mathrm{SD}$ and $\mathrm{AH}$ are joint first authors.

Received 02 July 2020

Revised 09 0ctober 2020

Accepted 26 October 2020

Check for updates

(c) Author(s) (or their employer(s)) 2020. Re-use permitted under CC BY-NC. No commercial re-use. See rights and permissions. Published by BMJ.

${ }^{1}$ Guy's and St Thomas' Hospitals NHS Trust, London, UK

${ }^{2}$ Faculty of Medicine, Imperial College of Science Technology and Medicine, London, UK

${ }^{3}$ Guy's Campus, King's College London School of Medicine, London, UK

Correspondence to Aleena Hossain; aleena.hossain16@imperial. ac.uk

\section{ABSTRACT}

Objectives To investigate perceptions of medical students on the role of online teaching in facilitating medical education during the COVID-19 pandemic.

Design Cross-sectional, online national survey.

Setting Responses collected online from $4^{\text {th }}$ May 2020 to $11^{\text {th }}$ May 2020 across 40 UK medical schools.

Participants Medical students across all years from UKregistered medical schools.

Main outcome measures The uses, experiences, perceived benefits and barriers of online teaching during the COVID-19 pandemic.

Results 2721 medical students across 39 medical schools responded. Medical schools adapted to the pandemic in different ways. The changes included the development of new distance-learning platforms on which content was released, remote delivery of lectures using platforms and the use of question banks and other online active recall resources. A significant difference was found between time spent on online platforms before and during COVID-19, with $7.35 \%$ students before versus $23.56 \%$ students during the pandemic spending $>15$ hours per week $(p<0.05)$. The greatest perceived benefits of online teaching platforms included their flexibility. Whereas the commonly perceived barriers to using online teaching platforms included family distraction (26.76\%) and poor internet connection (21.53\%). Conclusions Online teaching has enabled the continuation of medical education during these unprecedented times. Moving forward from this pandemic, in order to maximise the benefits of both face-to-face and online teaching and to improve the efficacy of medical education in the future, we suggest medical schools resort to teaching formats such as team-based/problem-based learning. This uses online teaching platforms allowing students to digest information in their own time but also allows students to then constructively discuss this material with peers. It has also been shown to be effective in terms of achieving learning outcomes. Beyond COVID-19, we anticipate further incorporation of online teaching methods within traditional medical education. This may accompany the observed shift in medical practice towards virtual consultations.

\section{INTRODUCTION}

Since the first case of coronavirus disease 2019 (COVID-19) in the UK, ${ }^{1}$ the WHO has
Strengths and limitations of this study

- The COVID-19 pandemic has undoubtedly impacted the delivery of medical education with a sudden shift towards online teaching platforms; to date, this is the first study investigating the perceptions of medical students on these changes.

- This study is strengthened by its collection of responses from a large national cohort of medical students from 39 out of 40 UK medical schools.

- The survey extensively explored the benefits of and barriers to online teaching methods with the potential to provide medical schools nationally with a direction for development of resources.

- Survey responses may have been subject to recall bias, and limited by timing of the study coinciding with the examination season where remote learning platforms may often be resorted to.

declared the COVID-19 outbreak as a global pandemic. ${ }^{2}$ The nationwide lockdown restrictions to control the spread of disease and 'flatten the curve' have impacted all aspects of life ${ }^{3-5}$ inevitably, medical education has also been affected, with the halting of lectures, clinical placements and key examinations. ${ }^{67}$ Such measures have resulted in a sudden shift in teaching methods towards online teaching. Online teaching has played a key role in medical education over recent years, ${ }^{8-10}$ demonstrated several benefits in enhancing student learning. ${ }^{11}$ A recent systematic review suggested that offline teaching and online teaching are equivalent in terms of outcomes of examinations. ${ }^{12}$ Key drawbacks have also been highlighted, including time constraints to implement effective online teaching. ${ }^{8}$

The unprecedented COVID-19 pandemic has caused a sudden shift towards the exclusive adoption of online teaching, forming the primary source of medical education and enabling students to continue to learn 
remotely. ${ }^{13}$ Teaching sessions have covered key clinical conditions, case studies and examination questions via live-streamed tutorials through platforms such as Zoom, ${ }^{6}$ shown to have high levels of engagement. ${ }^{14}$ With around $19.6 \%$ of the UK medical student demographic consisting of international students, ${ }^{15}$ many of whom have returned home, this allows individuals to access teaching regardless of location. ${ }^{6}$ Nevertheless, learning relying on the Internet needs to be tailored towards different learning styles to enable it to be impactful and effective. ${ }^{13}$ However, while the benefits to preclinical years of blended learning has been shown, for example, in anatomical teaching ${ }^{16}$ and especially in a generation accustomed to using YouTube, ${ }^{17}$ there is limited understanding of the impact of exclusive online teaching and its use in clinical years. Concerns have been raised regarding the quality of resources produced during the pandemic due to time constraints, particularly as these resources aim to compensate for lack of exposure. ${ }^{18}$ Indeed, a recent national Twitter discussion, involving representatives from the General Medical Council, NHS (National Health Service) England and WHO, found that a key concern among students was that remote learning impacted their ability to develop clinical competence. ${ }^{19}$ This also highlighted the potential role of the professional use of social media in facilitating medical education, as shown in surgical training. ${ }^{20}$

In the coming months, as lockdown restrictions ease, the need for social distancing will continue and the possibility of medical students acting as vectors of COVID-19, ${ }^{21}{ }^{22}$ as seen in the SARS (severe acute respiratory syndrome) epidemic in Hong Kong, ${ }^{23}$ remains. Moreover, PPE (personal protective equipment) shortages may form potential barriers to patient interaction. ${ }^{24}$ Therefore, it is likely that e-learning and telemedicine will continue to form vital sources of medical education. Many authors have suggested that digital health platforms for both patients and students will remain an integral part of care even after the COVID-19 pandemic. ${ }^{25}$ Thus, having a greater understanding of the perceived advantages and drawbacks will allow medical schools to improve their delivery of online teaching. The COVID-19 pandemic has put us in a unique position to evaluate the significance of online teaching platforms in medical education. While many students have acknowledged the impact of COVID-19 on their education ${ }^{621}$ and explored their role during the pandemic, ${ }^{26}{ }^{27}$ to date no study has investigated the outlook of medical students on the effect of these changes. Therefore, we aimed to investigate their perceptions on the role of online teaching in facilitating their education during the COVID-19 pandemic. Improving our understanding of this could help develop medical school curricula in the future.

\section{METHODOLOGY}

\section{Questionnaire design and distribution}

This was a cross-sectional study conducted on a national level via an online survey. A 20-item questionnaire was devised following a literature search on current online teaching methods and the effects of COVID-19 on medical education in the UK (online supplemental appendix 1). Questions exploring the experiences of online teaching were based on sections I to IV of the Dundee Ready Education Environment Measure (DREEM), ${ }^{28}$ a validated questionnaire designed to measure the educational environment of medical schools and healthcare professionals. ${ }^{29}$ These were 5-point Likert-type questions, ranging from strongly disagree to strongly agree. The remaining items in the questionnaire comprised a mixture of question styles. Certain questions were conditional. Open-ended text responses were also collected and underwent thematic analysis whereby responses were categorised. The question items were initially drafted and informally discussed with a group of medical students before undergoing a careful review and editing process. The final questions explored the following three themes: 1. General demographics.

2. The use and experience of online teaching during the COVID-19 pandemic.

3. Perceived benefits and barriers of online teaching.

The survey was created using Qualtrics, an online survey software (V.XM, 2019, Provo, $\mathrm{Utah}^{30}$ ), and distributed by medical students recruited nationally via social media, with an interest in sharing a national survey, in order to maximise outreach to all 40 registered UK medical schools. ${ }^{31}$ The survey was accessible via an anonymous link and open for a 1-week period (04 May 2020 to 11 May 2020).

\section{Participants}

All 42190 undergraduate and graduate entry medical students ${ }^{32}$ across all years (years 1 to 5 and intercalated year) from 40 registered UK medical schools $^{31}$ were eligible to participate.

\section{Patient and public involvement}

As this study focussed on medical students, patients or the general public were not involved in the study design. However, medical students were involved with the piloting of the survey as well as its distribution across medical schools.

\section{Participant consent and ethical considerations}

Participation was voluntary, and participants were informed prior to starting the survey that all data collected was non-identifiable and would only be used for research purposes. A mandatory selection box consenting to participation and confirming that this was the first time completing this survey was included at the beginning of the survey, ensuring a $100 \%$ consent rate and preventing multiple responses.

\section{Data analysis}

Data was exported from Qualtrics to Microsoft Excel (Excel V.16.29, 2019). Qualtrics and GraphPad Prism (Prism V.8.2.1, 2019) were both used to generate graphs and calculate descriptive statistics for the survey responses 
to explore patterns in responses. Multiple responses were accounted for by identifying unique IP (Internet Protocol) addresses.

Wilcoxon test was used to compare hours of online teaching usage before and during COVID-19 overall, while Mann-Whitney U test was used in a subgroup analysis comparing usage between preclinical and clinical students. These were conducted following the ShapiroWilk and Kolmogorov-Smirnov normality tests which found the data set to be non-gaussian in distribution. $\mathrm{P}$ values $<0.05$ were considered statistically significant.

\section{RESULTS}

\section{Cohort demographics}

Of the 2721 responses collected, $68.06 \%(\mathrm{n}=1852)$ of respondents were women, $31.53 \%(\mathrm{n}=858)$ were men and $0.40 \%(n=11)$ identified as other, contrasting against the population of UK medical students, which comprises of $55 \%$ women and $45 \%$ men. $^{32}$ Responses were collected from 39 medical schools across the UK, from medical students across all years (table 1). Due to the inability to track the survey distribution, it was not possible to calculate a response rate. However, non-response bias was minimised by ensuring the survey was shared by a variety of medical students via a range of platforms.

\section{Student engagement with online teaching platforms}

Prior to the pandemic, students spent an average of 4 to 6 hours per week using online teaching platforms. Students used a combination of video tutorials (27.71\%), online question banks (26.18\%), pre-recorded tutorials via their respective medical schools $(20.96 \%)$ and online flashcards $(15.99 \%)$. Live tutorials via online platforms from their medical school were used by $4.46 \%$ of students, while $1.79 \%$ used live tutorials from other sources (figure 1). Other resources included the use of Anatomy TV, online notes such as Pulsenotes or TeachMeAnatomy, Acland's Anatomy videos, revision websites, for example, OSCEstop and Zero To Finals, NICE (National Institute for Health and Care Excellence) guidelines, online textbooks and UpToDate and BMJ Best Practice.

Students then ranked the effectiveness of online teaching platforms with 1 being most effective and 5 being least effective. According to the responses by the students, video tutorials, for example, YouTube/Osmosis appeared to be the most effective, followed by online question banks, and live tutorials, while students commented using a variety of other sources. However, following subanalysis and exclusion of intercalating students, unlike preclinical students, clinical students found live tutorials to be the most effective, although rankings for the remaining platforms were similar.

During the pandemic, students spent an average of 7 to 10 hours using online teaching platforms, compared with 4 to 6 hours prior to the pandemic. The difference in hours prior to and during the COVID-19 pandemic were found to be significant $(p<0.05)$. Similar numbers
Table 1 A table outlining the demographics (gender, university and year of medical school) of students responding to the survey $(n=2721)$

\begin{tabular}{|c|c|c|}
\hline \multicolumn{2}{|c|}{ Demographic } & \multirow{2}{*}{$\begin{array}{l}\text { Proportion } \\
\text { of students, } \\
\% \text { (n) }\end{array}$} \\
\hline Gender & Male & \\
\hline & Female & $68.06(1852)$ \\
\hline & Other & $0.40(11)$ \\
\hline \multirow[t]{28}{*}{ University } & $\begin{array}{l}\text { University of Aberdeen School of } \\
\text { Medicine and Dentistry }\end{array}$ & $1.76(48)$ \\
\hline & $\begin{array}{l}\text { Anglia Ruskin University School of } \\
\text { Medicine }\end{array}$ & $2.21(60)$ \\
\hline & Aston University Medical School & $0.07(2)$ \\
\hline & $\begin{array}{l}\text { Barts and The London School of } \\
\text { Medicine and Dentistry }\end{array}$ & $6.39(174)$ \\
\hline & $\begin{array}{l}\text { University of Birmingham College of } \\
\text { Medical and Dental Sciences }\end{array}$ & $1.76(48)$ \\
\hline & Brighton and Sussex Medical School & $0.44(12)$ \\
\hline & University of Bristol Medical School & $3.20(87)$ \\
\hline & $\begin{array}{l}\text { University of Buckingham Medical } \\
\text { School }\end{array}$ & $0.77(21)$ \\
\hline & $\begin{array}{l}\text { University of Cambridge School of } \\
\text { Clinical Medicine }\end{array}$ & $1.29(35)$ \\
\hline & Cardiff University School of Medicine & $9.22(251)$ \\
\hline & $\begin{array}{l}\text { University of Dundee School of } \\
\text { Medicine }\end{array}$ & $0.40(11)$ \\
\hline & $\begin{array}{l}\text { The University of Edinburgh Medical } \\
\text { School }\end{array}$ & $0.44(12)$ \\
\hline & University of Exeter Medical School & $2.06(56)$ \\
\hline & $\begin{array}{l}\text { University of Glasgow School of } \\
\text { Medicine }\end{array}$ & $0.70(19)$ \\
\hline & Hull York Medical School & $3.86(105)$ \\
\hline & $\begin{array}{l}\text { Imperial College London Faculty of } \\
\text { Medicine }\end{array}$ & $3.93(107)$ \\
\hline & Keele University School of Medicine & $0.85(23)$ \\
\hline & Kent and Medway Medical School & $0.04(1)$ \\
\hline & $\begin{array}{l}\text { King's College London GKT School } \\
\text { of Medical Education }\end{array}$ & $10.11(275)$ \\
\hline & Lancaster University Medical School & $0.15(4)$ \\
\hline & $\begin{array}{l}\text { University of Leeds School of } \\
\text { Medicine }\end{array}$ & $4.96(135)$ \\
\hline & $\begin{array}{l}\text { University of Leicester Medical } \\
\text { School }\end{array}$ & $2.87(78)$ \\
\hline & $\begin{array}{l}\text { University of Liverpool School of } \\
\text { Medicine }\end{array}$ & $8.38(228)$ \\
\hline & $\begin{array}{l}\text { University of Manchester Medical } \\
\text { School }\end{array}$ & $4.52(123)$ \\
\hline & $\begin{array}{l}\text { Newcastle University School of } \\
\text { Medical Education }\end{array}$ & $3.34(91)$ \\
\hline & Norwich Medical School & $7.02(191)$ \\
\hline & $\begin{array}{l}\text { University of Nottingham School of } \\
\text { Medicine }\end{array}$ & $3.31(90)$ \\
\hline & $\begin{array}{l}\text { University of Nottingham - Lincoln } \\
\text { Medical School }\end{array}$ & $0.07(2)$ \\
\hline
\end{tabular}

Continued 
Table 1 Continued

\begin{tabular}{|c|c|c|}
\hline Demographic & & $\begin{array}{l}\text { Proportion } \\
\text { of students, } \\
\% \text { (n) }\end{array}$ \\
\hline & $\begin{array}{l}\text { University of Oxford Medical } \\
\text { Sciences Division }\end{array}$ & $2.24(61)$ \\
\hline & $\begin{array}{l}\text { Plymouth University Peninsula } \\
\text { Schools of Medicine and Dentistry }\end{array}$ & $0.55(15)$ \\
\hline & $\begin{array}{l}\text { Queen's University Belfast School of } \\
\text { Medicine }\end{array}$ & $0.92(25)$ \\
\hline & $\begin{array}{l}\text { University of Sheffield Medical } \\
\text { School }\end{array}$ & $0.99(27)$ \\
\hline & $\begin{array}{l}\text { University of Southampton School of } \\
\text { Medicine }\end{array}$ & $1.98(54)$ \\
\hline & $\begin{array}{l}\text { University of St Andrews School of } \\
\text { Medicine }\end{array}$ & $0.33(9)$ \\
\hline & St George's, University of London & $2.46(67)$ \\
\hline & $\begin{array}{l}\text { University of Sunderland School of } \\
\text { Medicine }\end{array}$ & $0.00(0)$ \\
\hline & Swansea University Medical School & $0.11(3)$ \\
\hline & $\begin{array}{l}\text { University of Central Lancashire } \\
\text { School of Medicine }\end{array}$ & $1.73(47)$ \\
\hline & $\begin{array}{l}\text { University College London Medical } \\
\text { School }\end{array}$ & $2.46(67)$ \\
\hline & $\begin{array}{l}\text { University of Warwick Medical } \\
\text { School }\end{array}$ & $2.09(57)$ \\
\hline \multirow[t]{6}{*}{ Year } & Preclinical year 1 & $23.19(631)$ \\
\hline & Preclinical year 2 & $19.85(540)$ \\
\hline & Year 3 & $27.20(740)$ \\
\hline & Penultimate clinical year & $20.62(561)$ \\
\hline & Final clinical year & $4.52(123)$ \\
\hline & Intercalating & $4.63(126)$ \\
\hline
\end{tabular}

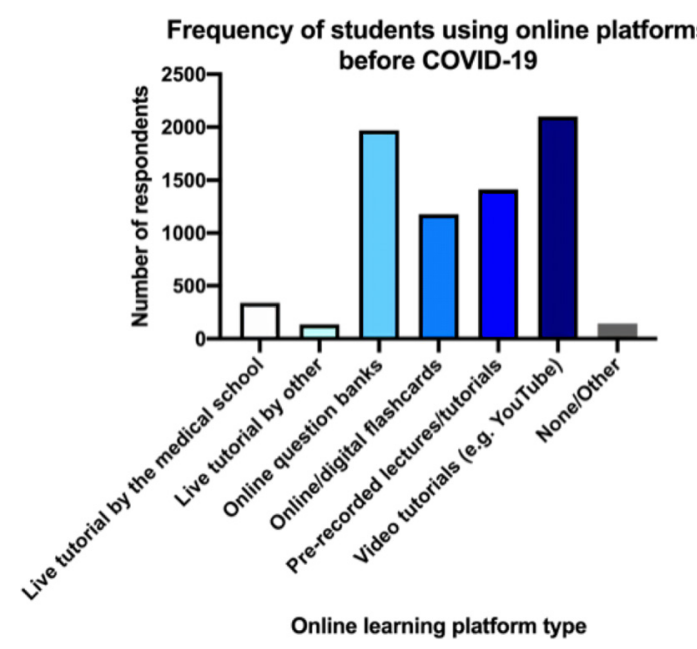

Figure 1 Students were asked about the different types of online teaching platforms they used before the COVID-19 pandemic as represented by this bar chart $(n=2721)$. Options included live tutorial by the medical school, live tutorial by other sources, online question banks, online/digital flashcards, pre-recorded lectures/tutorials, video tutorials, for example, YouTube, none or other. of students spent $<1$ hour on online teaching platforms before and during the pandemic. However, there was an increase in numbers of students spending longer periods of time on online teaching platforms, for example, $7.35 \%(\mathrm{n}=200)$ versus $19.70 \%(\mathrm{n}=641)$ of students spent $>15$ hours on online teaching platforms before and during the pandemic (figure 2A). Following subanalysis, before the pandemic, clinical and preclinical students spent similar times on online teaching (figure 2Bi), whereas during the pandemic differences in periods were found to be significant $(\mathrm{p}<0.001)$ (figure 2Bii), with a greater proportion of preclinical students spending $>15$ hours ( $28.69 \%$ vs $20.01 \%$ ). Taking examinations remotely were reported by $57.28 \%$ of students; the remaining reported having postponed or cancelled examinations.

\section{Medical school adaptations to COVID-19}

Medical schools adapted to the pandemic in a combination of ways with $28.48 \%$ of students reporting their medical school to adapting to remote learning through the delivery of live tutorials via online platforms. Moreover, $42.19 \%$ of students reported that their medical school either introduced new resources to existing learning platforms or created a new online teaching platform with new resources. Other medical schools have either (1) not implemented anything as the curriculum had already been covered, or (2) delayed teaching with the introduction of a question bank.

The online teaching provided as an alternative by the medical schools followed a pre-set curriculum for $66.12 \%$ $(\mathrm{n}=1799)$ of students, was designed following student requests for $3.38 \%(\mathrm{n}=92)$ of students, or using a combination of both for $30.50 \% \quad(\mathrm{n}=830)$ of students. This shows that student opinion was considered in the delivery of online teaching.

Furthermore, 59.73\% of students found that online teaching sessions have been interactive, with students finding the opportunity to interact via the chat box or by directly speaking to the lecturer. Some students have also specified that having small group sizes, group discussions, online case simulations and quizzes have been useful in increasing their engagement.

\section{Student perception of online teaching}

Students ranked their experience of online teaching using a Likert scale with 1 being strongly disagree and 5 being strongly agree (table 2). Overall, students did not find online teaching to be engaging or enjoyable, with limited opportunities to ask questions. Furthermore, on average students were neutral when asked whether online teaching should be more interactive, but did not find it as effective as face-to-face teaching.

The main advantages of online teaching appeared to be that it saves students time on travelling (19.82\%), provides flexibility $(19.52 \%)$, the ability for students to learn at their own pace $(18.63 \%)$, it is more comfortable $(15.84 \%)$ and it cuts costs (14.24\%) (figure 3A). Other medical students $(n=82)$ also commented that it provides 


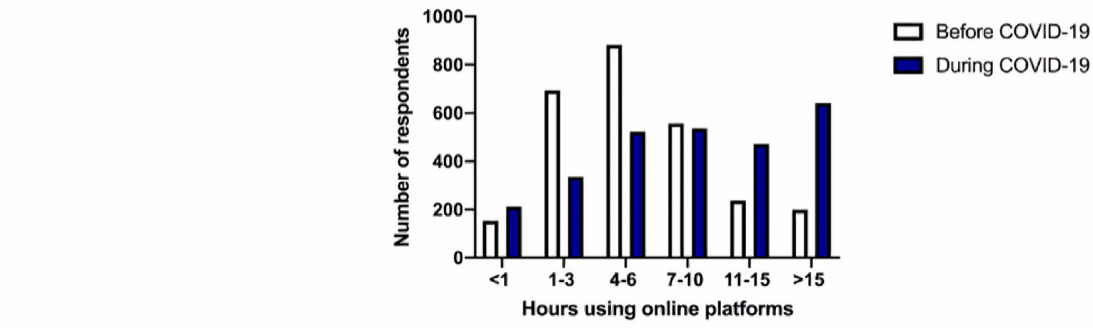

$\mathrm{Bi}$

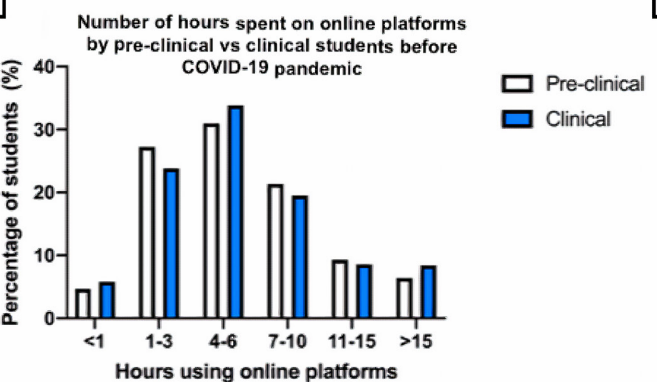

B ii

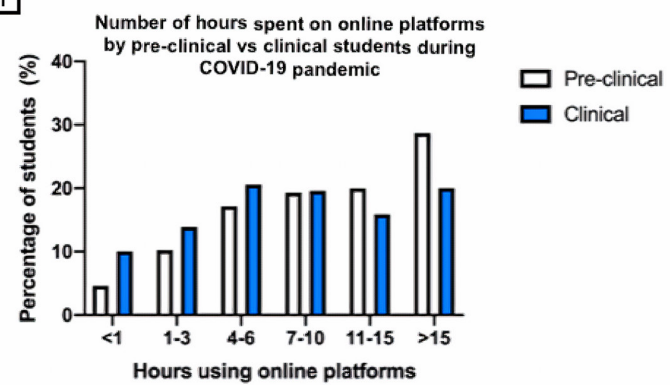

Figure 2 Students were asked the approximate number of hours spent on online teaching platforms before and during the COVID-19 pandemic ( $n=2721)$. (A) A bar graph comparing the number of hours spent on online platforms before and during the COVID-19 pandemic by students overall. A Wilcoxon test was then conducted which found the difference to be significant $(p<0.05)$. (B i) A bar graph comparing the number of hours spent on online platforms by preclinical and clinical students before the COVID-19 pandemic. (B ii) A bar graph comparing the number of hours spent on online platforms by preclinical and clinical students during the COVID-19 pandemic. A Mann-Whitney $U$ test found the difference in time spent between the students during the COVID-19 pandemic to be significant $(p<0.001)$.

time efficiency, allows more time for students to focus on preparing for clinical placements, reduces anxiety and being able to be in a different country.

On the other hand, students stated that family distractions $(26.76 \%)$, Internet connection $(21.53 \%)$, timing

Table 2 A table displaying students' perceptions on their experiences of online teaching, ranked on a Likert scale from 1 to 5 , where $1=$ strongly disagree and $5=$ strongly agree. Likert scores have been shown as mean $\pm S D$

\begin{tabular}{|c|c|c|}
\hline Statement & Mean & $\pm S D$ \\
\hline The teaching is often stimulating & 2.75 & 1.18 \\
\hline I find it easy to engage in the lesson & 2.55 & 1.30 \\
\hline I feel able to ask the questions I want & 2.70 & 1.53 \\
\hline I enjoy the online teaching & 2.62 & 1.37 \\
\hline $\begin{array}{l}\text { I would like the online teaching to be more } \\
\text { interactive }\end{array}$ & 3.04 & 1.44 \\
\hline $\begin{array}{l}\text { I feel that online teaching is as effective as } \\
\text { face-to-face teaching }\end{array}$ & 1.92 & 1.45 \\
\hline $\begin{array}{l}\text { I prefer online teaching to face-to-face } \\
\text { teaching }\end{array}$ & 1.69 & 1.48 \\
\hline $\begin{array}{l}\text { The teachers are well prepared for the } \\
\text { teaching sessions }\end{array}$ & 3.36 & 1.42 \\
\hline $\begin{array}{l}\text { I feel I am being well prepared for my } \\
\text { profession }\end{array}$ & 2.28 & 1.33 \\
\hline My Internet connection can be problematic & 2.53 & 1.74 \\
\hline
\end{tabular}

of tutorials (17.31\%), anxiety (11.08\%) and lack of space $(11.03 \%)$ as barriers to effective online teaching (figure 3B). Students $(n=81)$ commented on experiencing a lack of motivation, difficulty concentrating and asking questions and a lack of contact with colleagues as further limitations.

Role of online teaching in clinical teaching

The feeling that online teaching had not successfully replaced the clinical teaching they received via direct patient contact was felt by $75.99 \%(\mathrm{n}=1842)$ of the medical students, with $82.17 \%(n=1986)$ feeling they cannot learn practical clinical skills through online teaching. This shows that clinical skills remain a pertinent barrier to online teaching of medical students.

\section{DISCUSSION \\ Background}

With the rise of COVID-19, it is unsurprising that many medical institutions have resorted to online education platforms. However, online education has been used preceding this pandemic. Here, we discuss how this pandemic has shaped the use of online teaching currently as well as its application in the future of medical education.

The impact of COVID-19 on uptake of online teaching

Our study found a significant increase in the time spent on online teaching platforms before and during the 
A

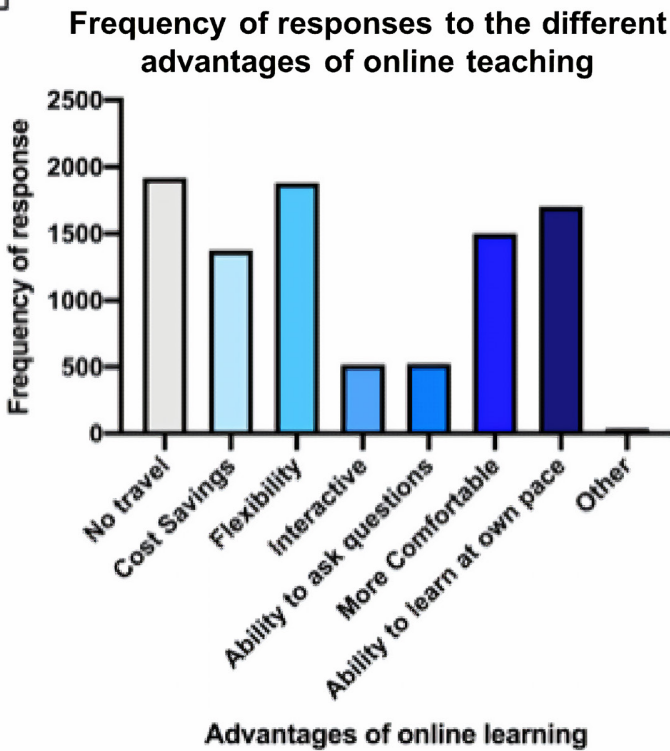

B

Frequency of responses to the different advantages of online teaching

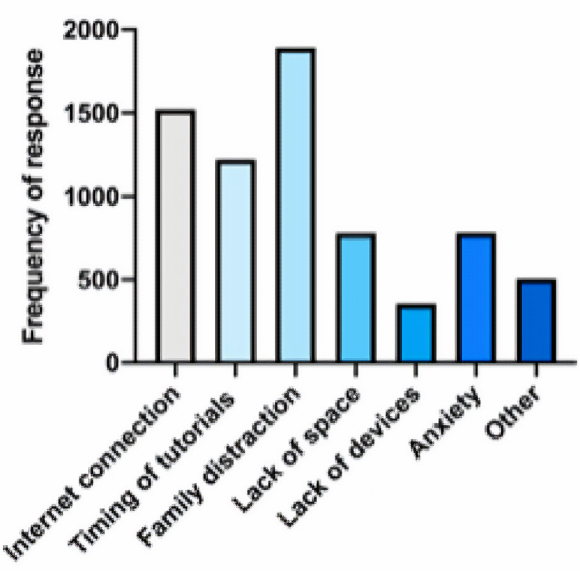

Barriers to online learning

Figure 3 A bar chart outlining the advantages of and barriers to online teaching. (A) Students were provided with a list of potential ways in which online teaching was advantageous and they were asked to select all which applied to them. They were also given the option to input their own statements $(n=2721)$. (B) Students were provided with a list of potential barriers to the benefits they may receive from online teaching and they were asked to select all which applied to them. They were also given the option to input their own statements $(n=2721)$.

pandemic $(\mathrm{p}<0.05)$, particularly among preclinical students. This was expected, as the primary source of education and engagement of students with their medical school was online, in addition to the pre-existing use of online teaching resources. This is despite the reported cancellation of clinical examinations and conversion of written examinations into open book, which would arguably reduce student engagement. Hence, the cancellation of clinical examinations may have accounted for the greater proportion of preclinical students engaging with online teaching for more than 15 hours, which is greater than that of clinical students.

The development of innovative educational projects has been initiated to enhance remote medical education. ${ }^{19}$ A rise in external resources and teaching programmes such as Osmosis, BiteMedicine, Becoming A Doctor and Sustaining Medical education in a Lockdown Environment (SMILE) has allowed many teaching sessions to be available to medical students across the country. Hence, students may learn from a wider community of professionals. However, the high flow of resources causes a proliferation of choice which may increase burnout rates. Schwartz claimed that this choice overload is due to the failure of universities on fulfilling their education role to their students. ${ }^{33}{ }^{34}$ Yet, although some platforms were created to facilitate learning during lockdown (eg, SMILE), many diverse medical education platforms available existed prior to the pandemic with increasing usage, which may suggest that students desire this flexible curriculum.

Our results suggest that students would like online teaching sessions to be more interactive. This could be achieved via student response systems incorporating methods such as polls, quizzes or breakout rooms, ${ }^{3536}$ which have been shown to encourage student participation. ${ }^{37}$ Indeed, previous literature suggests the incorporation of online Q\&A sessions to improve student engagement, ${ }^{13}$ based on a previous model advising the use of synchronous learning. ${ }^{38}$ Synchronous learning is defined as a social learning environment alongside answering questions live. ${ }^{39}$ This active communication between lecturers and students allows ambiguous concepts to be addressed immediately to increase student involvement, creating a more active learning environment.

\section{Student perception of online teaching}

Students scored their experiences of online compared with face-to-face teaching to be lower, with an average of 1.69 scored for preference for online teaching, and 2.55 for engagement in lessons (table 2), suggesting most students prefer face-to-face teaching. Furthermore, previous studies using the DREEM survey found higher average scores for educational environments. ${ }^{40-42}$ The discrepancies found may have been due to students comparing their current experiences to previous face-toface teaching. However, given that students are currently solely limited to online teaching, responses may not truly reflect the efficacy of online teaching. Nevertheless, as online teaching has become mainstream, it is paramount to analyse its efficacy compared with previous methods for further development.

Furthermore, unlike teaching evaluated by DREEM previously, the current pandemic caused a sudden shift towards the use of online teaching on a large scale, 
allowing for inconsistencies with underdeveloped medical curricula, many teachers being inadequately prepared and technical difficulties. ${ }^{8}$ Therefore, the low scores of student experiences may be due to the unexpected, sudden introduction of online teaching. Despite the relatively high score of 3.36 for teacher preparation, ${ }^{40-47}$ the quality of the sessions delivered may have been impacted by several factors such as poor internet connection, family distractions and the timing of the tutorials, as demonstrated by our results. In the future, medical schools must carefully build an infrastructure comprising of technologically versatile lecturers to deliver well-organised, succinct tutorials, games and resources, especially given the lack of awareness of 'conscientious online lecture design' among medical educators. ${ }^{48}$

The low score of 2.28 for being 'well prepared for my profession' (table 2), compared with previous studies reporting up to $3.18,{ }^{41} 43464749$ is striking, mirroring concerns that remote or online teaching may compromise the clinical competence and confidence of students. ${ }^{19}$ The loss of immediate feedback may have contributed to this, as generally students and doctors prefer face-to-face sessions for communication ${ }^{50}$ and feedback purposes. ${ }^{51}$ Nonetheless, it is important to note that students often do not feel completely prepared for their profession. ${ }^{52}$

Moreover, overall video tutorials (eg, YouTube or Osmosis), were ranked as the most effective online resources, compared with live tutorials, particularly for preclinical students. Reasons for this may include the short, organised and aesthetic nature of pre-recorded videos. ${ }^{53}$ In comparison, live tutorials tend to be longer, face technical difficulties and are less engaging. Despite these challenges, live tutorials were perceived to be the most effective by clinical students. This may be due to the sessions' synchronous nature, allowing for real-time discussions to occur, reflecting clinical practice.

Notably, in this study, distinctions between the different forms of online teaching were not made when investigating students' perceptions. Rather, it was an evaluation of online teaching as a whole, which may have impacted the results, as teaching modalities are often specific to the topic being taught. ${ }^{48}$ Furthermore, student preferences may depend on the purpose of engaging with resources, for example, for learning new content versus revision, ${ }^{54}$ or for short-term versus long-term knowledge retention. ${ }^{55}$

\section{Benefits and barriers of online teaching}

To students, the main advantages of online teaching are the time and money saved from the lack of travel, its flexibility and the ability for students to learn at their own pace (figure 3A). Further benefits of live online lectures ${ }^{14}$ include opportunities for students to anonymously ask and answer questions, potentially encouraging further engagement from those who would not otherwise participate in a live lecture, due to the less intimidating environment online.$^{56}$ However, these benefits may not be applicable to all forms of online teaching. For example, the limited synchronous aspects of pre-recorded content may deter students due to the lack of opportunities to interact with lecturers. ${ }^{57}$ Also, watching pre-recorded lectures, alongside the possibility of attending face-toface lecture, has been shown to negatively correlate with learning success. ${ }^{58}$

The main barriers to online teaching appear to be family distractions, Internet connection and the timing of tutorials (figure 3B). This may disadvantage students with large families or with limited Internet access. Moreover, the mental health of students, recently shown to be impacted by the COVID-19 pandemic, ${ }^{59}$ may be adversely affected as indicated by the free text responses. This may be, in part, attributed to the lack of interaction with friends and colleagues leading to a rise in anxiety. Alternatively, with exams being open book and with an unrestricted setting, students may be less prone to exam anxiety. ${ }^{60}$ Although, this does not address the family and noise disturbances which may still affect exam performance.

\section{Medical student role during the COVID-19 pandemic}

On the other hand, medical students are being asked to 'step-up' and join the front-line of doctors tackling COVID-19. ${ }^{61}$ As well as the early graduation of UK medical students, ${ }^{62}$ many universities have given their students the opportunity to volunteer. For example, the University of Birmingham has facilitated for over 700 medical students to volunteer in the NHS. ${ }^{27}$ Although medical schools have halted clinical placements, this opportunity could provide more exposure, undoubtedly impacting the development of medical students. However, for those who are not volunteering due to living with vulnerable family members or having health conditions themselves, this would then put them at a disadvantage as their peers continue to gain clinical exposure.

As lockdown restrictions ease and students slowly return to medical school, clinical placements may incorporate more virtual aspects as healthcare evolves. ${ }^{22}$ Indeed, new platforms have been developed by the NHS (eg, NHS Near Me) which have shown that video consultations are better than telephone consultations in reducing medical error and improving patient outcomes. ${ }^{31}$ However, Professor Martin Marshall, chairman of the Royal College of General Practitioners, has highlighted that most consultations are still taking place over the phone as opposed to video calls. ${ }^{63}$ This may be subject to change with a demographic who are increasingly familiar with the use of the Internet. Additionally, in Germany, online platforms as observed in Dermatology may "provide a safe and efficient alternative for face-to-face outpatient care', ${ }^{25}$ abiding by social distancing rules.

\section{Future direction of online teaching}

Furthermore, the digitalisation of medical teaching could play a significant role in the future of medical schools. Allowing users to tailor their learning and acquire new skills through the chaotic nature of an amplitude of resources could halt the development of medical students. Having discussed benefits of both face-to-face and remote 
teaching as well as the future of healthcare online, we suggest that in order to maximise the benefits of these learning methods, a mixture of online and in-person teaching should be used moving forward. This can be incorporated into an effective learning method such as problem-based learning (PBL) or team-based learning (TBL) which have been shown to improve learning outcomes, ${ }^{6465}$ student motivation and understanding. ${ }^{66}$ Students are set online materials to study and are then are expected to discuss content in person in a group tutorial. ${ }^{67}$ This allows students to study at their own pace, in a manner suitable to them, while also holding them accountable for their own learning. While students find PBL sessions to be interactive and to improve self-directed learning, ${ }^{68} 69$ TBL has been found to be more engaging and 'conducive to learning' in preclinical settings, due to smaller groups, ensuring timely tutor feedback. ${ }^{70}$

Compared with face-to-face teaching, students in this study felt less satisfied with online teaching and illprepared for their profession. With many of these students due to graduate as doctors in the next few years, this is concerning, highlighting the need for medical schools to improve their delivery of medical education given that online teaching is here to stay. Hence, we suggest that until innovative solutions are generated, medical schools adopt TBL or PBL learning styles for efficiently delivering high-yielded teaching.

\section{Limitations and future work}

This is the first study to look at the impact of COVID-19 on online teaching across the UK, with responses from $39 / 40$ medical schools. One of the strengths of this study is its large sample size of 2792 medical student across all preclinical and clinical years. Furthermore, the recruitment of a variety of medical students for survey distribution via a range of methods minimised potential response bias. However, this study also had some limitations. Some medical schools may have been disproportionately represented with larger numbers of responses from some schools, for example, King's College London, compared with newer medical schools such as Aston or Kent, potentially skewing results due to sample bias. Additionally, $68.06 \%$ of participants were women, in comparison to $55 \%$ of UK medical students who are women; ${ }^{32}$ thus, the results may not be generalisable to the medical student population. Further, some aspects of this survey depended on participants' memory perhaps influencing their reporting, introducing elements of recall bias. The survey did not evaluate the various ways different content may have been taught, for example, online lectures, games or question banks; perceptions of game-based online anatomy teaching would have differed from online didactic lectures on immunology. Thus, we cannot truly evaluate the types of online teaching provided. Also, it is important to note that the period covered is usually when students have examinations, hence students may have been spending more time on online teaching platforms regardless. In addition, since this survey, medical schools may have updated their online resources. Lastly, student receptivity to PBL/TBL methods should have been evaluated. To truly measure the impact of COVID-19 on student utilisation of online teaching, a more in-depth, qualitative analysis such as focus groups conducted in collaboration with medical schools is required to gather more accurate results, such as the effects on examination performance.

Acknowledgements We thank Bonita Sinartio, Shweta Madhusudanan, Harri Gruffydd Jones, Victoria Selwyn, Rebecca Conway-Jones, Aqsa Javed, Esmée Nourizadeh, Jack Alan Tagg, Ayshia Bibi, Hyacyntha Celine Hazna Imelda, Sonya Gibson, Kauther Al-Kaaby, Sharma Kansal, Muzammil Ali Khan, Haya Maki and Maryam Goralwalla, for their assistance in distributing the survey link and collecting data. We would also like to express our gratitude to our supervisor, Dr Samiullah Dost, for his guidance and support throughout the course of this study.

Contributors SD contributed to the study concept and design, and developed the questionnaire. SD recruited collaborators for survey distribution and data collection. SD supervised the project, had full access to the data, controlled the decision to publish and accepts full responsibility for the conduct of this study, as the guarantor. $\mathrm{AH}$ and $\mathrm{SD}$ contributed equally to this study as joint first authors. AH developed and designed the questionnaire, contributed to data acquisition and interpretation, writing and critical revision of the manuscript. AH is the corresponding author and managed project administration. MS developed the questionnaire, contributed to data acquisition and interpretation, and writing and critical revision of the manuscript. AA developed the questionnaire, and contributed to data visualisation and presentation, and writing and critical revision of the manuscript. LA-N performed data analysis, interpretation, visualisation and presentation and contributed to writing and critical revision of the manuscript. All authors approved the final version to be published and are accountable for all aspects of the work. Sixteen students were involved with survey distribution and data collection.

Funding The authors have not declared a specific grant for this research from any funding agency in the public, commercial or not-for-profit sectors.

Competing interests None declared.

Patient consent for publication Not required.

Ethics approval Ethical approval was requested from Imperial College London and was deemed not to be required as all data was anonymised, with informed consent taken from all participants. The work was carried out in accordance with the Declaration of Helsinki, including, but not limited to the anonymity of participants being guaranteed and the informed consent of participants being obtained.

Provenance and peer review Not commissioned; externally peer reviewed.

Data availability statement Data are available upon reasonable request from the corresponding author (ah2716@ic.ac.uk). Due to the anonymous nature of the survey, it was not possible to disseminate the results of this study to the participants.

This content has been supplied by the author(s). It has not been vetted by BMJ Publishing Group Limited (BMJ) and may not have been peer-reviewed. Any opinions or recommendations discussed are solely those of the author(s) and are not endorsed by BMJ. BMJ disclaims all liability and responsibility arising from any reliance placed on the content. Where the content includes any translated material, BMJ does not warrant the accuracy and reliability of the translations (including but not limited to local regulations, clinical guidelines, terminology, drug names and drug dosages), and is not responsible for any error and/or omissions arising from translation and adaptation or otherwise.

Open access This is an open access article distributed in accordance with the Creative Commons Attribution Non Commercial (CC BY-NC 4.0) license, which permits others to distribute, remix, adapt, build upon this work non-commercially, and license their derivative works on different terms, provided the original work is properly cited, appropriate credit is given, any changes made indicated, and the use is non-commercial. See: http://creativecommons.org/licenses/by-nc/4.0/.

\section{ORCID iDs}

Samiullah Dost http://orcid.org/0000-0001-9088-613X

Aleena Hossain http://orcid.org/0000-0003-3484-3578

Mai Shehab http://orcid.org/0000-0003-3405-6283 
Aida Abdelwahed http://orcid.org/0000-0002-4729-8399

Lana Al-Nusair http://orcid.org/0000-0003-4820-1584

\section{REFERENCES}

1 Moss P, Barlow G, Easom N, et al. Lessons for managing highconsequence infections from first COVID-19 cases in the UK. Lancet 2020;395:E46.

2 World Health Organisation. WHO announces COVID-19 outbreak a pandemic. [Online] World Health Organisation. Available: http:// www.euro.who.int/en/health-topics/health-emergencies/coronaviruscovid-19/news/news/2020/3/who-announces-covid-19-outbreak-apandemic [Accessed 31 May 2020].

3 Johnson B. PM address to the nation on coronavirus: 23 Mar 2020. [Online] GOV.UK. Available: https://www.gov.uk/government/ speeches/pm-address-to-the-nation-on-coronavirus-23-march-2020 [Accessed 29th May 2020].

4 Hancock M. Controlling the spread of COVID-19: Health Secretary's statement to Parliament. [Online] GOV.UK. Available: https://www. gov.uk/government/speeches/controlling-the-spread-of-covid-19health-secretarys-statement-to-parliament [Accessed 31 May 2020]

5 Stevens S, Pritchard A. Letter to chief executives of all NHS trusts and foundation trusts, CCG accountable officers, GP practices and primary care networks, and providers of community health services. [Online] NHS England and NHS Improvement. Available: https:// www.england.nhs.uk/coronavirus/wp-content/uploads/sites/52/ 2020/03/urgent-next-steps-on-nhs-response-to-covid-19-lettersimon-stevens.pdf [Accessed 29 May 2020].

6 Sandhu P, de Wolf M. The impact of COVID-19 on the undergraduate medical curriculum. Med Educ Online 2020;25:1764740.

7 General Medical Council. Information for medical students. [Online] General Medical Council. Available: https://www.gmc-uk.org/news/ news-archive/coronavirus-information-and-advice/information-formedical-students [Accessed 27 May 2020].

8 O'Doherty D, Dromey M, Lougheed J, et al. Barriers and solutions to online learning in medical education - an integrative review. BMC Med Educ 2018;18:s12909-018-1240-0.

9 Harden RM. Trends and the future of postgraduate medical education. Emerg Med J 2006;23:emj.2005.033738:798-802.

10 Moran J, Briscoe G, Peglow S. Current technology in advancing medical education: perspectives for learning and providing care. Acad Psychiatry 2018;42:s40596-018-0946-y:796-9.

11 Lochner L, Wieser H, Waldboth S, et al. Combining traditional anatomy lectures with e-learning activities: how do students perceive their learning experience? Int J Med Educ 2016;7:69-74.

12 Pei L, Wu H. Does online learning work better than offline learning in undergraduate medical education? A systematic review and metaanalysis. Med Educ Online 2019;24:1666538.

13 Evans DJR, Bay BH, Wilson TD, et al. Going virtual to support anatomy education: a STOPGAP in the midst of the Covid-19 pandemic. Anat Sci Educ 2020;13:279-83.

14 Kay D, Pasarica M. Using technology to increase student (and faculty satisfaction with) engagement in medical education. Adv Physiol Educ 2019;43:408-13.

15 Universities UK International. International facts and figure 2019. [Online] Universities UK International. Available: https://www. universitiesuk.ac.uk/International/Documents/2019/International facts and figures slides.pdf [Accessed 30 May 2020].

16 Khalil MK, Abdel Meguid EM, Elkhider IA. Teaching of anatomical sciences: a blended learning approach. Clin Anat 2018;31:ca.23052:323-9.

17 Barry DS, Marzouk F, Chulak-Oglu K, et al. Anatomy education for the YouTube generation. Anat Sci Educ 2016:9:90-6.

18 Longhurst GJ, Stone DM, Dulohery K, et al. Strength, weakness, opportunity, threat (SWOT) analysis of the adaptations to anatomical education in the United Kingdom and Republic of Ireland in response to the Covid-19 pandemic. Anat Sci Educ 2020;13:301-11.

19 Huddart D, Hirniak J, Sethi R, et al. \#MedStudentCovid: How social media is supporting students during COVID-19. Med Educ 2020:medu.14215.

20 Gallo G, Sturiale A, De Simone V, et al. Epistemic networks on Twitter: a new way to learn. Journal of Investigative Surgery 2019;100:1-9.

21 Ahmed H, Allaf M, Elghazaly H. COVID-19 and medical education. Lancet Infect Dis 2020;20:777-8.

22 Rose S. Medical student education in the time of COVID-19. JAMA 2020;323:2131-2.

23 Wong T-wai, Lee C-kei, Tam W, et al. Cluster of SARS among medical students exposed to single patient, Hong Kong. Emerg Infect Dis 2004;10:269-76.
24 Roberts M. Coronavirus: Has the NHS got enough PPE?. [Online] BBC News. Available: https://www.bbc.co.uk/news/health-52254745 [Accessed 31 May 2020].

25 Reinholz M, French LE. Medical education and care in dermatology during the SARS-CoV2 pandemia: challenges and chances. J Eur Acad Dermatol Venereol 2020;34:e214-6.

26 Representatives of the STARSurg Collaborative, EuroSurg Collaborative, and TASMAN Collaborative. Medical student involvement in the COVID-19 response. Lancet 2020;395:1254.

27 Watson A, McKinnon T, Prior S-D, et al. COVID-19: time for a BOLD new strategy for medical education. Med Educ Online 2020;25:1764741.

28 Roff S, McAleer S, Harden RM, et al. Development and validation of the Dundee ready education environment measure (DREEM). Med Teach 1997;19:295-9.

29 Miles S, Swift L, Leinster SJ. The Dundee ready education environment measure (DREEM): a review of its adoption and use. Med Teach 2012;34:e620-34.

30 Qualtrics. Qualtrics[Online] Provo, Utah, USA, 2019. Available: https://www.qualtrics.com

31 Medical Schools Council. Medical schools A-Z. Available: https:// www.medschools.ac.uk/studying-medicine/medical-schools [Accessed 28 May 2020].

32 General Medical Council. The state of medical education and practice in the UK, 2019. Available: https://www.gmc-uk.org/-/ media/documents/the-state-of-medical-education-and-practicein-the-uk---workforce-report_pdf-80449007.pdf [Accessed 20 Aug 2020].

33 Schwartz B. The tyranny of choice. Sci Am 2004;290:70-5.

34 Ackerman DS, Gross BL. How many choices are good? measurement of the effects of course choice on perceptions of a marketing option. Journal of Marketing Education 2006;28:69-80.

35 McBrien JL, Cheng R, Jones P. Virtual spaces: employing a synchronous online classroom to facilitate student engagement in online learning. IRRODL 2009;10.

36 Muir S, Tirlea L, Elphinstone B, et al. Promoting classroom engagement through the use of an online student response system: a mixed methods analysis. Journal of Statistics Education 2020;28:25-31.

37 Morawo A, Sun C, Lowden M. Enhancing engagement during live virtual learning using interactive quizzes. Med Educ 2020:medu.14253.

38 Chen Nian-Shing, Ko Hsiu-Chia, Chen NS, et al. A model for synchronous learning using the Internet. Innovations in Education and Teaching International 2005;42:181-94.

39 Hrastinski S. Asynchronous \& Synchronous E-Learning. EDUCAUSE Quarterly, 2008. Available: https://er.educause.edu/-/media/files/ article-downloads/eqm0848.pdf [Accessed 28 May 2020].

40 Prashanth GP, Ismail SK. The Dundee ready education environment measure: a prospective comparative study of undergraduate medical students' and interns' perceptions in Oman. Sultan Qaboos Univ Med J 2018;18:173-81.

41 Miles S, Leinster SJ. Medical students' perceptions of their educational environment: expected versus actual perceptions. Med Educ 2007;41:265-72.

42 Patil AA, Chaudhari VL. Students' perception of the educational environment in medical college: a study based on DREEM questionnaire. Korean J Med Educ 2016;28:281-8.

43 Dunne F, McAleer S, Roff S. Assessment of the undergraduate medical education environment in a large UK medical school. Health Educ J 2006;65:149-58.

44 Palés J, Gual A, Escanero J, et al. Educational climate perception by preclinical and clinical medical students in five Spanish medical schools. Int J Med Educ 2015;6:65-75.

45 Demirören M, Palaoglu O, Kemahli S, et al. Perceptions of students in different phases of medical education of educational environment: Ankara university faculty of medicine. Med Educ Online 2008;13:8.

46 Dreyer A, Gibbs A, Smalley S, et al. Clinical Associate students' perception of the educational environment at the University of the Witwatersrand, Johannesburg. Afr J Prim Health Care Fam Med 2015;7:778

47 Riquelme A, Oporto M, Oporto J, et al. Measuring students perceptions of the educational climate of the new curriculum at the Pontificia Universidad Católica de Chile: Performance of the Spanish translation of the Dundee Ready Education Environment Measure (DREEM). Education for Health: Change in Learning and Practice 2009;22:112.

48 Tang B, Coret A, Qureshi A, et al. Online lectures in undergraduate medical education: Scoping review. JMIR Med Educ 2018;4:e11.

49 Finn Y, Avalos G, Dunne F. Positive changes in the medical educational environment following introduction of a new systems- 
based curriculum: DREEM or reality? curricular change and the environment. Ir J Med Sci 2014;183:253-8.

50 Paechter M, Maier B. Online or face-to-face? Students' experiences and preferences in e-learning. Internet High Educ 2010;13:292-7.

51 Ifediora CO. Online medical education for doctors: identifying potential gaps to the traditional, face-to-face modality. J Med Educ Curric Dev 2019;6:1-8

52 Monrouxe LV, Grundy L, Mann M, et al. How prepared are UK medical graduates for practice? a rapid review of the literature 20092014. BMJ Open 2017;7:e013656.

53 Guo PJ, Kim J, Rubin R. How video production affects student engagement: an empirical study of MOOC videos. L@S 2014 Proceedings of the 1st ACM Conference on Learning at Scale, 2014.

54 Wynter L, Burgess A, Kalman E, et al. Medical students: what educational resources are they using? BMC Med Educ 2019;19:36

55 Rondon S, Sassi FC, Furquim de Andrade CR. Computer gamebased and traditional learning method: a comparison regarding students' knowledge retention. BMC Med Educ 2013;13:30.

$56 \mathrm{Ni}$ AY, Ya Ni A. Comparing the effectiveness of classroom and online learning: teaching research methods. J Public Aff Educ 2013;19:199-215.

57 Keis O, Grab C, Schneider A, et al. Online or face-to-face instruction? A qualitative study on the electrocardiogram course at the University of Ulm to examine why students choose a particular format. BMC Med Educ 2017;17:194.

58 Zureick AH, Burk-Rafel J, Purkiss JA, et al. The interrupted learner: how distractions during live and video lectures influence learning outcomes. Anat Sci Educ 2018;11:366-76.

59 Cao W, Fang Z, Hou G, et al. The psychological impact of the COVID-19 epidemic on college students in China. Psychiatry Res 2020;287:112934.
60 Stowell JR, Bennett D. Effects of online testing on student exam performance and test anxiety. Journal of Educational Computing Research 2010;42:161-71.

61 Mahase E. Covid-19: medical students to be employed by NHS as part of epidemic response. BMJ 2020;368:m1156.

62 British Medical Association. COVID-19: early provisional registration for final year students. [Online] BMA - COVID-19. Available: https:// www.bma.org.uk/advice-and-support/covid-19/returning-to-the-nhsor-starting-a-new-role/covid-19-early-provisional-registration-forfinal-year-students [Accessed 28 May 2020].

63 Lynch P, Wainwright D. Coronavirus: How GPs have stopped seeing most patients in person. [Online] BBC News. Available: https://www. bbc.co.uk/news/uk-england-52216222 [Accessed 31 May 2020].

64 EHJ Y, Goh K. Problem-Based learning: an overview of its process and impact on learning. Health Professions Education 2016;2:75-9.

65 Clark CE. Problem-Based learning: how do the outcomes compare with traditional teaching? Br J Gen Pract 2006;56:722-3.

66 Klegeris A, Hurren H. Impact of problem-based learning in a large classroom setting: student perception and problem-solving skills. Adv Physiol Educ 2011;35:408-15.

67 Chang BJ. Problem-Based learning in medical school: a student's perspective. Ann Med Surg 2016;12:88-9.

68 Yadav RL, Piryani RM, Deo GP, et al. Attitude and perception of undergraduate medical students toward the problem-based learning in Chitwan medical College, Nepal. Adv Med Educ Pract 2018;9:317-22.

69 Al-Drees AA, Khalil MS, Irshad M, et al. Students' perception towards the problem based learning tutorial session in a system-based hybrid curriculum. Saudi Med J 2015;36:341-8.

70 Burgess A, Bleasel J, Haq I, et al. Team-Based learning (TBL) in the medical curriculum: better than PBL? BMC Med Educ 2017;17:243. 